\title{
Technology Shocks and Employment in Open Economies
}

\author{
Juha Tervala* \\ University of Helsinki and HECER \\ University of Helsinki, Department of Economics \\ Discussion Paper No. 628:2007 \\ ISBN 978-952-10-2776-5, ISSN 1459-3696
}

March 2, 2007

\begin{abstract}
A growing body of empirical evidence suggests that a positive technology shock leads to a persistent decline in employment. A twocountry model is used to demonstrate that the open economy dimension can enhance the ability of sticky price models to account for the evidence. The reason is as follows. An improvement in technology appreciates the nominal exchange rate. Under producer-currency pricing, the exchange rate appreciation shifts global demand toward foreign goods away from domestic goods. This causes a persistent decline in domestic employment. If the expenditure switching effect is sufficiently strong, a technology shock also has a negative effect on output in the short run.
\end{abstract}

Keywords: Open economy macroeconomics, technology shocks, employment

JEL classification: F41, E32, E24

${ }^{*}$ E-mail address: juha.tervala@helsinki.fi

Financial support from the Yrjö Jahnsson Foundation is gratefully acknowledged. I am grateful to Pertti Haaparanta, Tapio Palokangas and Antti Ripatti for comments. 


\section{Introduction}

In an influential paper, Gali (1999) examines the effects of technology shocks on output and employment (hours worked) using a structural VAR approach. He shows that a positive technology shock causes a permanent increase in output, but the increase in output is more gradual than that of labor productivity. In the short run, output changes little or may even fall. The gap between the initial increase in output and the increase in productivity is reflected in a temporary, though persistent and significant, decline in employment. After the initial response, employment and output gradually increase. In the long run, employment returns to the initial level and output reaches a permanently higher level.

A growing body of empirical literature has focused on the connection between technological changes and macroeconomic fluctuations. Recent empirical work supports the results of Gali (1999): Technology shocks have a negative effect on employment in the short run. ${ }^{1}$ The negative empirical relationship between productivity and employment has called into question the empirical relevance of Real Business Cycle (RBC) models and the view that technological changes are the driving force behind business cycles.

One strand of the literature has focused on explaining why the response of employment to a positive technology shock is negative. As pointed out by Gali and Rabanal (2004, Section 4), there are two broad classes of factors which are absent in standard RBC models and which can explain this result. The first category can be referred to as "nominal explanations", since they rely on the presence of nominal frictions. Explanations in the second category are based on extended RBC models and do not lean on nominal rigidities. Thus, they can be referred to as "real explanations".

Several authors have extended standard (closed economy) RBC models to explain the fall in employment. Francis and Ramey (2005) use a calibrated RBC model to show that habit formation and capital adjustment costs imply that a technology shock can cause a decline in employment. A similar mechanism is proposed by Uhlig (2004) who shows that capital income taxation and labor hoarding can explain the decline in employment. Francis and Ramey (2005) also show that a labor-augmenting technical process with extremely low capital-labor substitution can also explain the fall in employment. Rotemberg (2003) demonstrates that extremely low technology adaptation means that employment declines in response to a technology

\footnotetext{
${ }^{1}$ This literature includes Basu, Fernald and Kimball (2004), Carlsson (2003), Francis, Owyang and Theodorou (2003), Francis and Ramey (2004, 2005), Franco and Philippon (2007), Gali (2004) and Gali and Rabanal (2004). On the other hand, Christiano, Eichenbaum and Vigfusson (2004) find that employment rises after a technology shock. They show that Gali's (1999) results are sensitive to specifying the VAR in terms of the level (as opposed to the first difference) of employment. However, other empirical work finds evidence that Gali's (1999) results are robust to using different VAR specifications, data sets and measures for technolocigal changes.
} 
shock.

Collard and Dellas $(2004,2007)$ develop a two-country RBC model to show that a technology shock may cause a decline in employment if the elasticity of substitution between domestic and foreign goods is very low. Sufficiently low substitutability implies that a technology shock causes a significant deterioration of the terms of trade. The deterioration in the relative price of domestic goods discourages output expansion. Employment declines because the level of output increases less than proportionally to the increase in productivity.

The most important nominal explanation is presented by Gali (1999), who develops a sticky price model to explain why the effect of a technology shock on employment can be negative. In his model, the relationship $y_{t}=m_{t}-p_{t}$ holds in equilibrium, prices are set in advance and the central bank follows a simple money supply rule. When technology improves, employment declines unless the central bank expands the money supply at least in proportion to the improvement in technology. Gali (2003) demonstrates that this result generalizes to a model with staggered price setting. When technology improves, only a fraction of firms lower their prices in the short run. The aggregate price level declines and consequently aggregate demand increases. Aggregate demand may increase less than proportionally to the improvement in technology if the fraction of firms adjusting their prices is sufficiently small. Employment may therefore decline.

In this paper, we develop a two-country general equilibrium model to address the question of how technology shocks affect output and employment in open economies. The model is based on Betts and Devereux (2000). The model's basic structure is quite identical to Gali's (2003) closed economy model. We extend the Betts-Devereux model in two ways. First, we introduce shocks to the production technology. Second, we introduce Calvotype staggered price setting. The assumption of staggered pricing allows for richer dynamic responses to technology shocks than the hypothesis of simultaneous one-step-ahead pricing. These richer dynamics are important for a realistic discussion of the relationship between technology shocks and employment.

In this paper, we show that the open economy dimension can enhance the ability of sticky price models to account for the empirical findings of Gali (1999). In an open economy, there is an additional factor that can cause a decline in employment and output in the short run: the expenditure switching effect of a nominal exchange rate change. An improvement in technology causes an appreciation of the exchange rate. In the case of producer-currency pricing (PCP), the appreciation raises the relative price of domestic goods, shifting global demand toward foreign goods away from domestic goods. This causes an additional decline in domestic employment in the short run. The decline in employment is therefore sharper and more persistent in open economies. On the other hand, in the case of local- 
currency pricing (LCP), the appreciation has no expenditure-switching role in the short run. In this case, a technology shock causes a decline in employment that is almost the same as in the closed economy. In this respect our finding is different than that of Corsetti and Pesenti (2005) who find that exchange rate pass-through has no impact on employment, following a technology shock. In this model, after the initial response, employment and output start to gradually increase. In the long run, employment shows no significant change relative to the pre-shock level and output reaches a permanently higher level, consistent with the empirical evidence. In addition, we demonstrate that under PCP (LCP) a technology shock generates a negative (positive) effect on foreign welfare in the short run.

Our finding, regarding the role of the elasticity of substitution between domestic and foreign goods, is dissimilar to that of Collard and Dellas (2004, 2007). As mentioned, the authors show that, under flexible prices, low elasticity discourages output expansion and consequently causes a fall in employment. With nominal rigidities, the elasticity of substitution between domestic and foreign goods is a key variable in determining the strength of the expenditure switching effect. Thus, we show that a decline in domestic employment depends positively on the elasticity of substitution between domestic and foreign goods in the short run.

The rest of the paper is organized as follows. Section 2 presents the model. Section 3 discusses the international transmission of country-specific technology shocks. As the title suggests, we pay special attention to the effects of technology shocks on employment. Finally, section 4 concludes the paper.

\section{The Model}

To study the macroeconomic effects of technology shocks, we develop a model that extends the framework of Betts and Devereux (2000). As mentioned in the introduction, the model is modified in two ways. The first modification is simple: the introduction of productivity shocks. The second is the introduction of Calvo-type staggered price setting. This allows us to assess the consequences of technology shocks for the persistence of employment changes.

\subsection{Country Size and Market Structure}

The world economy consists of two countries, home and foreign. There is a continuum of firms and households distributed on the unit interval. The number of households and firms is normalized to unity and they are indexed by $z \in[0,1]$. A fraction $n$ of household and firms are domestic, and $1-n$ are foreign. 
Each firm produces a differentiated good, however, there are two types of firms. A fraction $b$ of firms in each country can "price-to-market". These firms set their prices in the currency of the buyer. We refer to these firms as LCP firms. A fraction $1-b$ of firms set a unified price across the countries. These firms set their prices in the currency of the producer and we refer to these firms as PCP firms.

\subsection{Households}

All households have identical preferences. Households derive utility from consumption $C_{t}$ and from real balances $M_{t} / P_{t}$ but they dislike work $\ell_{t}$. The representative domestic household seeks to maximize

$$
U_{t}(z)=\sum_{s=t}^{\infty} \beta^{s-t}\left[\log C_{s}+\frac{\chi}{1-\varepsilon}\left(\frac{M_{s}}{P_{s}}\right)^{1-\varepsilon}-\frac{\ell_{s}(z)^{2}}{2}\right] .
$$

Here, $\beta$ is the discount factor, $\chi$ and $\varepsilon$ are positive parameters. The composite consumption index is defined as

$$
C_{t}=\left[\int_{0}^{1} c_{t}(z)^{\frac{\theta-1}{\theta}} d z\right]^{\frac{\theta}{\theta-1}}
$$

where $c_{t}(z)$ is consumption of good $z$ at time $t$ and $\theta$ is the elasticity of substitution between consumption goods. The consumption-based price index is given by

$P_{t}=\left[\int_{0}^{n} p_{t}(z)^{1-\theta} d z+\int_{n}^{n+(1-n) b} p_{t}\left(z^{*}\right)^{1-\theta} d z+\int_{n+(1-n) b}^{1}\left(E_{t} q_{t}\left(z^{*}\right)\right)^{1-\theta} d z\right]^{\frac{1}{1-\theta}}$,

where prices $p$ represent domestic currency prices, prices $q$ represent foreign currency prices and $E$ is the exchange rate (the domestic currency price of foreign currency). In general, foreign country variables are indicated by asterisks but in the context of goods prices an asterisk means a price set by foreign firm $z^{*}$. Thus, $p_{t}(z)$ is the domestic currency price of the domestically-produced good, $p_{t}\left(z^{*}\right)$ is the domestic currency price of foreign $\operatorname{good} z^{*}$ and $q_{t}\left(z^{*}\right)$ is the foreign currency price of a foreign good.

Households receive an earned income, dividends from firms and transfers from the government (seigniorage revenues). Households use income to purchase consumption goods and to accumulate money and a nominal bond. Each household owns an equal share of all domestic firms. There is free and costless trade in a nominal bond which is denominated in domestic currency. The budget constraint is given by

$$
M_{t}+\delta_{t} D_{t}=D_{t-1}+M_{t-1}+w_{t} \ell_{t}(z)-P_{t} C_{t}+\pi_{t}+P_{t} \tau_{t}
$$


where $\delta_{t}$ is the nominal price of the bond $\left(\delta_{t}=\left(1+i_{t}\right)^{-1}\right.$, where $i_{t}$ is the nominal interest rate) maturing in period $t+1, D_{t}$ holdings of the bond, $w_{t}$ is the nominal wage, $\pi_{t}$ nominal dividends (profits) and $\tau_{t}$ is the transfers from the government. The government rebates all seigniorage revenues to households:

$$
\tau_{t}=\frac{M_{t}-M_{t-1}}{P_{t}} .
$$

Since the bond is denominated in domestic currency, the budget constraint of foreign households is

$$
M_{t}^{*}+\delta_{t}^{*} \frac{D_{t}^{*}}{E_{t}}=\frac{D_{t-1}^{*}}{E_{t}}+M_{t-1}^{*}+w_{t}^{*} \ell_{t}^{*}(z)-P_{t}^{*} C_{t}^{*}+\pi_{t}^{*}+P_{t}^{*} \tau_{t}^{*} .
$$

The global asset-market-clearing condition requires $n D_{t}+(1-n) D_{t}^{*}=0$.

Households maximize the utility function subject to the budget constraint. The first order conditions for the maximization problem of domestic and foreign households are

$$
\begin{gathered}
\delta_{t} P_{t+1} C_{t+1}=\beta P_{t} C_{t}, \\
\delta_{t}^{*} P_{t+1}^{*} C_{t+1}^{*} E_{t+1}=\beta P_{t}^{*} C_{t}^{*} E_{t}, \\
\ell_{t}=\frac{w_{t}}{C_{t} P_{t}}, \\
\ell_{t}^{*}=\frac{w_{t}^{*}}{C_{t}^{*} P_{t}^{*}}, \\
\frac{M_{t}}{P_{t}}=\left(\frac{\chi C_{t}}{1-\delta_{t}}\right)^{\frac{1}{\varepsilon}}, \\
\frac{M_{t}^{*}}{P_{t}^{*}}=\left(\frac{\chi C_{t}^{*}}{1-\frac{\delta_{t}^{*} E_{t+1}}{E_{t}}}\right)^{\frac{1}{\varepsilon}} .
\end{gathered}
$$

Equation (5) and (6) are consumption Euler equations. Equations (7) and (8) govern the optimal labor supply. Finally, equations (9) and (10) govern the optimal money demand, money demand depends on consumption and the nominal interest rate.

\subsection{Firms}

\subsubsection{Technology and Profits}

Each firm produces a differentiated good with a production technology

$$
y_{t}(z)=a_{t} \ell_{t}(z)
$$


where $y_{t}(z)$ is the output of firm $z, a_{t}$ an exogenous technology parameter and $\ell_{t}(z)$ labor input used by firm $z$. Technology shocks are country specific and technology is assumed to follow an $\mathrm{AR}(1)$ process

$$
\hat{a}_{t}=\hat{a}_{t-1}+\epsilon_{t},
$$

where $\epsilon_{t}$ is an unpredictable shift in the level of domestic technology and hat notation is used to represent the percentage deviations from the initial steady state. Firms minimize costs $w_{t} \ell_{t}(z)$ subject to the above production function. The nominal marginal cost is

$$
M C_{t}(z)=\frac{w_{t}}{a_{t}} .
$$

Firms maximize profits taking into account the downwards-sloping demand for their products. As mentioned, there are two types of firms. PCP firms set a unified price across the countries. On the hand, LCP firms pricediscriminate across the countries. For LCP firms, total output is divided between output sold at home, $x_{t}(z)$, and output sold abroad, $v_{t}(z)$. Profits are given by

$$
\begin{gathered}
\pi_{t}^{P C P}(z)=p_{t}(z) y_{t}(z)-w_{t} \ell_{t}(z), \\
\pi_{t}^{L C P}(z)=p_{t} x_{t}(z)+E_{t} q_{t}(z) v_{t}(z)-w_{t} \ell_{t}(z), \\
\pi_{t}^{P C P}\left(z^{*}\right)=q_{t}\left(z^{*}\right) y_{t}^{*}\left(z^{*}\right)-w_{t}^{*} \ell_{t}^{*}\left(z^{*}\right), \\
\pi_{t}^{L C P}\left(z^{*}\right)=\left(p_{t}\left(z^{*}\right) v_{t}^{*}\left(z^{*}\right)\right) / E_{t}+q_{t}\left(z^{*}\right) x_{t}^{*}\left(z^{*}\right)-w_{t}^{*} \ell_{t}^{*}\left(z^{*}\right) .
\end{gathered}
$$

Equations (12) and (13) show the profits of a domestic PCP firm and of a LCP firm, respectively. Equations show (14) and (15) the profits of the corresponding foreign firms.

The demands for the products are given by

$$
\begin{gathered}
y_{t}(z)=\left(\frac{p_{t}(z)}{P_{t}}\right)^{-\theta} n C_{t}+\left(\frac{p_{t}(z)}{E_{t} P_{t}^{*}}\right)^{-\theta}(1-n) C_{t}^{*}, \\
x_{t}(z)=\left(\frac{p_{t}(z)}{P_{t}}\right)^{-\theta} n C_{t}, \\
v_{t}(z)=\left(\frac{q_{t}}{P_{t}^{*}}\right)^{-\theta}(1-n) C_{t}^{*}, \\
y_{t}^{*}\left(z^{*}\right)=\left(\frac{E_{t} q_{t}\left(z^{*}\right)}{P_{t}}\right)^{-\theta} n C_{t}+\left(\frac{q_{t}\left(z^{*}\right)}{P_{t}^{*}}\right)^{-\theta}(1-n) C_{t}^{*}, \\
v_{t}^{*}\left(z^{*}\right)=\left(\frac{p_{t}\left(z^{*}\right)}{P_{t}}\right)^{-\theta} n C_{t}, \\
x_{t}^{*}\left(z^{*}\right)=\left(\frac{q_{t}\left(z^{*}\right)}{P_{t}^{*}}\right)^{-\theta}(1-n) C_{t}^{*} .
\end{gathered}
$$

Equation (16) shows the demand for a domestic PCP firm. Equations (17) and (18) show the demand for a domestic LCP firm in domestic and foreign markets, respectively. Corresponding foreign equations are (19)-(21). 


\subsubsection{Price Setting}

In the absence of nominal rigidities, domestic LCP firms maximize $\pi_{t}^{L C P}(z)$ with respect to $p_{t}(z)$ and $q_{t}(z)$. This implies

$$
p_{t}(z)=E_{t} q_{t}(z)=\frac{\theta}{\theta-1} M C_{t}(z) .
$$

The assumption of an isoelastic demand function implies that the price of good $z$ a constant markup over marginal cost. Without nominal rigidities, the law of one price holds and good $z$ is sold at the same price in both markets, when expressed in the same currency. Domestic PCP firms maximize $\pi_{t}^{P C P}(z)$ with respect to $p_{t}(z)$. The price of good $z$ is a constant markup over marginal cost, the same as in equation (22).

With nominal rigidities, firms set the price at time $t$ before observing the realization of the technology shock. To model price rigidities, we follow the formulation of Calvo (1983). This formulation assumes that each firm rests its price in any given with a probability $1-\gamma$, independently of other firms and independently of the time elapsed since the last adjustment. Each firm has to take into account, when setting its profit-maximizing price, that in every subsequent period there is a probability $0<\gamma<1$ that it will not be able revise its price setting decision. When setting a new price in period $t$, each firm seeks to maximize the present value of profits weighting future profits by the probability that the price will still be effective in that period. For example, a domestic LCP firm seeks to maximize

$$
\max _{p_{t}(z), p_{t}^{*}(z)} V_{t}^{L C P}(z)=\sum_{s=t}^{\infty} \gamma^{s-t} \zeta_{t, s} \pi_{t}^{L C P}(z)
$$

where $\zeta_{s, t}=\Pi_{j=s}^{t}\left(1+i_{j}\right)^{-1}$ is the domestic nominal discount factor between period $t$ and period $s$. The result is that the pricing rules are given by

$$
\begin{aligned}
& p_{t}(z)=\left(\frac{\theta}{\theta-1}\right) \frac{\sum_{s=t}^{\infty} \gamma^{s-t} \zeta_{t, s} C_{s}\left(\frac{1}{P_{s}}\right)^{-\theta} M C_{s}(z)}{\sum_{s=t}^{\infty} \gamma^{s-t} \zeta_{t, s} C_{s}\left(\frac{1}{P_{s}}\right)^{-\theta}}, \\
& q_{t}(z)=\left(\frac{\theta}{\theta-1}\right) \frac{\sum_{s=t}^{\infty} \gamma^{s-t} \zeta_{t, s} C_{s}^{*}\left(\frac{1}{P_{s}^{*}}\right)^{-\theta} M C_{s}(z)}{\sum_{s=t}^{\infty} \gamma^{s-t} \zeta_{t, s} C_{s}^{*}\left(\frac{1}{P_{s}^{*}}\right)^{-\theta} E_{t}} .
\end{aligned}
$$

Equation (24) demonstrates that domestic export prices, expressed in foreign currency, do not change when the nominal exchanges rate moves. This implies that exchange rate pass-through to export prices is zero. The pricing rule for a domestic PCP good is the same as equation (23). This implies that $\mathrm{PCP}$ firms let foreign currency prices move one-to-one with the exchange 
rate, i.e. there is complete exchange rate pass-through to export prices. The pricing rules for foreign firms are the same as equations (23) and (24), except that the exchange rate should be replaced by $1 / E_{t}$ and prices, of course, depend on foreign marginal costs.

\subsection{Symmetric Equilibrium}

All firms in a country are symmetric and every firm that changes its price, in any given period, chooses the same price and output. The structure of price setting implies that each period a fraction of firms, $1-\gamma$, sets a new price and the remaining fraction keeps their price unchanged.

The consolidated budget constraint of the domestic economy is derived by substituting equations (3), (12), (13) into equation (2). Analogously, the consolidated budget constraint of the foreign economy is derived by using corresponding foreign equations and the asset-market-clearing condition. The consolidated budget constraints can be written as

$$
\begin{aligned}
\delta_{t} D_{t}=D_{t-1}+(1-b) p_{t}(z) x_{t}(z)+b\left[p_{t}(z) x_{t}(z)+E_{t} q_{t}(z) v(z)\right]-P_{t} C_{t} \\
-\frac{n}{1-n} \delta_{t}^{*} \frac{D_{t}}{E_{t}}=-\frac{n}{1-n} \frac{D_{t-1}}{E_{t}}+(1-b) q_{t}\left(z^{*}\right) y_{t}^{*}\left(z^{*}\right) \\
+b\left[q_{t}\left(z^{*}\right) x_{t}^{*}\left(z^{*}\right)+\frac{p_{t}\left(z^{*}\right) v_{t}^{*}\left(z^{*}\right)}{E_{t}}\right]-P_{t}^{*} C_{t}^{*}
\end{aligned}
$$

The model is log-linearized around a symmetric steady state where all exogenous variables, including technology, are constant. In addition, consider the special case where initial net foreign assets are zero and the level of technology is normalized to one. Those variables whose initial steady state value is zero are normalized by consumption. The log-linearization is implemented by expressing the model in terms of percentage deviations from the initial steady state. Equations (7), (11) and (22) imply that in initial equilibrium

$$
\bar{y}_{0}=\bar{\ell}_{0}=\left(\frac{\theta-1}{\theta}\right)^{\frac{1}{2}},
$$

where zero subscripts on barred variables denote initial steady state.

Equilibrium is sequences of variables that satisfy a number of conditions. First, the optimality conditions for consumption evolution, given by (5) and (6), must be satisfied. Second, the labor markets must be in equilibrium, in each country in each period. For example, under PCP, the domestic labor supply is given by (7) and the domestic labor demand is determined by the production function (11) and by the demand for goods (16). Four, the constant money supply must equal the demand for money, given by (9) and (10). Five, equilibrium must satisfy the optimal pricing rules. For example, 
domestic PCP firms set the new price based on equation (23). Finally, the intertemporal budget constraints, equations (25) and (26), must be satisfied.

\section{The International Transmission of Technology Shocks}

In this section we analyze the effects of technology shocks on employment and output and more generally the international transmission of technology shocks. First, since we use numerical simulations to solve the model, we briefly discuss the choice of parameter values. Then we discuss the international transmission of technology shocks under LCP. The next step is to discuss the international transmission of technology shocks under PCP. Finally, we implement a sensitivity analysis to study to what extent the effects of technology shocks on employment may be sensitive to the choice of some key parameter values.

\subsection{Parameterization}

The choice of parameter values follows Betts and Devereux (2001), with one exception. Betts and Devereux (2001) use these parameter values to study whether the international effects of monetary and fiscal policy are sensitive to the currency of export pricing. We believe these parameter values are the best values to examine the question of how the international effects of a technology shock depend on the currency of export pricing.

The rationale for the choice of parameter values is as follows. Periods are interpreted as quarters. Thus, we assume $\beta=0.99$ which implies a 4 percent annual real interest rate. The price adjustment parameter $\gamma$ is set to 0.75 . This implies that the average price duration is one year. The parameter $\chi$ is set to 1 . The parameter $\varepsilon$ governs the consumption and interest elasticity of money demand. In this model, the consumption elasticity of money demand is $1 / \varepsilon$. Empirical estimates of this elasticity are close to or below unity (Mankiw and Summer 1986; Helliwell et al. 1990). Following Betts and Devereux (2001), our baseline choice is $1 / \varepsilon=0.85$.

In this model, unlike in Betts and Devereux (2001), the same parameter $(\theta)$ governs the elasticity of substitution between two goods produced in the same country and the elasticity of substitution between two goods produced in different countries. Rotemberg and Woodford (1992) estimate that the former elasticity is about 6. Obstfeld and Rogoff (2000a, Section 2.3) briefly survey the literature on empirical estimates of the elasticity of substitution between domestic and foreign goods. They quote estimates in the range of 1.2 to 21.4. Typical estimates, however, are in the range of 5 to 6 . We set $\theta$ equal to 6 . This parameter value is widely used in the related literature, as e.g. in Sutherland (1996). 


\subsection{Simulation Results: The LCP Benchmark}

We begin by examining the effects of a domestic technology shock under full LCP $(b=1)$. Consider a one percent unexpected (permanent) increase in the level of technology occurring in period 1. The dashed lines in Figure 1 show the dynamic effects of a technology shock under LCP. In all figures, the vertical axes show percentage deviations from initial equilibrium. The change in bond holdings is, however, expressed as a deviation from initial consumption. The domestic terms of trade is the relative price of domestic imports in terms of domestic exports. So the domestic terms of trade deteriorates if this index rises. The change in utility in period $t$ is given $b^{2}$

$$
d U_{t}=\hat{C}_{t}-\bar{\ell}_{0}^{2} \hat{\ell}_{t}
$$

As can be seen from Figure 1, a technology shock causes a sharp, if only short-lived, decline in domestic employment. In the case of LCP, the reason for the decline in employment is virtually the same as in the closed economy model of Gali (2003), notwithstanding the fact that the present model is an open economy model. A technology shock lowers the marginal costs of all domestic firms. In the short, however, only a fraction of them have an opportunity to lower their prices. The aggregate price level starts to gradually adjust downward, increasing real balances and consequently aggregate demand. A technology shock therefore causes a gradual rise domestic output. In the short run, the rise in output is smaller than that of labor productivity. The gap between the increase in labor productivity and the initial rise in output is reflected in a temporary fall in employment.

With full LCP, an exchange rate appreciation does not change relative prices. Money market equilibrium requires either a rise in relative consumption of the home country or a fall in the (relative) domestic nominal interest rate. Since exchange rate overshooting is extremely small, money market equilibrium implies an instant rise in relative domestic consumption. ${ }^{3}$ Thus, domestic households also raise current consumption by running a current account deficit. A permanent rise in output naturally leads to a permanently higher level of consumption.

Due to the LCP assumption, the main economic effects of an exchange rate change are on the profits of firms. With import and domestic prices sticky, an exchange rate appreciation does not switch demand from domestic goods to foreign goods. An exchange rate change instead generates a distribution of income. When domestic firms price their exports in foreign currency, an exchange rate appreciation reduces their profits measured in domestic currency terms [recall equation (13)]. On the other hand, an

\footnotetext{
${ }^{2}$ As standard in the literature, we neglect the utility derived from real balances.

${ }^{3}$ As in Betts and Devereux (2000), the nominal exchange rate overshoots its long run level if $\varepsilon>1$. Because $\varepsilon$ is almost 1, exchange rate overshooting is extremely small.
} 
exchange rate appreciation raises the profits of foreign firms measured in foreign currency terms.

It is worth noting that, under LCP, the effect of a technology shock on domestic employment is almost the same as it would be in the closed economy $(n \rightarrow 1)$. One main reason for this is that there is no expenditure switching effect of a nominal exchange rate change. It is also worth observing that the effect of a technology shock on employment is positive in the long run, albeit the effect is extremely small. The home country runs a current account deficit and thus lower long run wealth leads to a small increase in the labor supply. The opposite change occurs in the foreign country. However, we should not overstate this effect because it is extremely weak. In the closed economy, a technology shock would not have impact on the labor supply in the long run, as in Gali (2003).

Panel (d) of Figure 1 demonstrates that a domestic technology shock also has a positive influence on foreign consumption. This is due to three factors. First, as mentioned an exchange rate appreciation distributes income toward the foreign economy in the short run. Second, a domestic technology shock improves the foreign terms of trade. In the short, under LCP, a domestic currency appreciation causes an improvement in the foreign county's terms of trade. In the long run, an increase in the supply of domestic goods decreases the relative price of domestic goods. So the change in the terms of trade raises foreign consumption in real terms. Third, the accumulation of external assets enables foreign households to increase their consumption.

Panel (i) illustrates the welfare effects of a technology shock. It is welfare enhancing in both countries in every period. The intuition behind this result is straightforward. An improvement in the level of technology allows domestic households to consume more without having to increase labor supply. On the contrary, labor supply is reduced in the short run. As mentioned, the accumulation of external assets and the improvement in the foreign terms of trade have a positive effect on foreign consumption. A technology shock therefore has a positive spillover effect.

\subsection{The Expenditure Switching Effect and Employment}

As emphasized by e.g. Obstfeld and Rogoff (2000b), the expenditure switching effect of a nominal exchange rate change is a key concept in the Keynesian approach to international macroeconomics. The traditional argument goes that, when a country's currency appreciates, it experiences an increase in the relative price of its exports and thereby shifting world consumption away from its products. The authors present empirical evidence that supports the traditional framework and the assumption of PCP. They therefore underline that the expenditure switching effect "should be a central feature of open economy models" (ibid, 127).

The next step is to analyze the international transmission of technology 
shocks in the case where import prices move with the exchange rate. The solid lines in Figure 1 show the effects of the same unexpected increase in domestic technology, under full PCP $(b=0)$. Figure 1 illustrates that PCP has important implications for the economies' adjustment to a domestic technology shock, especially for output and employment dynamics in the short run.

In the case of PCP, the expenditure switching effect of a nominal exchange rate change is to blame for a remarkable fall in domestic output. Under PCP, the relative consumption change increases the relative demand for domestic money. This requires an appreciation of the domestic currency. Due to the assumption of PCP, there is one-to-one pass-through of exchange rate changes to import prices. The nominal exchange rate appreciation increases the relative price of domestic exports, shifting foreign demand toward foreign goods away from domestic goods. At the same time, the exchange rate appreciation implies that domestic goods become more expensive relative to foreign goods in the home country. Thus, domestic demand shifts toward foreign goods too. These expenditure switching effects imply that the exchange rate appreciation causes a fall in domestic output and a rise in foreign output in the short run. Since the impact of a technology shock on the nominal exchange rate is fairly strong and that prices are relatively sticky, so the expenditure switching effect is quite strong. Thus, a technology shock causes a significant fall in domestic output and a significant rise in foreign output in the short run. When domestic firms have an opportunity to reset their prices, domestic goods become cheaper relative to foreign goods and the expenditure switching effect gradually dies out.

Panel (e) in Figure 1 shows that, in the case of PCP, a technology shock causes a more persistent and significant decline in domestic employment than in the LCP benchmark. As before, the gap between the increase in output and the increase in technology is reflected in a decline in employment. The expenditure switching effect, of course, accounts for the addition decline in employment. As mentioned, in the LCP case, the impact of a technology shock is almost the same as in the closed economy. Thus, we can also conclude that the expenditure switching effect causes an additional decline in employment relative to the closed economy case.

Complete exchange rate pass-through to import prices has the opposite effect on domestic and foreign consumption in the short run. The exchange rate appreciation lowers the domestic price level, raising domestic consumption in real terms. The exchange rate change, on the other hand, increases the foreign price level, reducing foreign consumption in real terms in the short run. In the long run, the accumulation of external assets and the improvement in the foreign terms of trade have a positive effect on foreign consumption.

Panel (h) demonstrates that, in the case of PCP, a technology shock induces an improvement in the domestic terms of trade in the short run. A 
domestic currency appreciation lowers import prices measured in domestic currency terms. In the short run, this "exchange rate effect" dominates. On the other hand, an increase in the supply of domestic goods implies a fall in the relative price of domestic goods. So the terms of trade deteriorates in the long run.

Panel (i) shows that, in the case of PCP, a technology shock has a "beggar-thy-neighbor" effect in the short run. Foreign consumption falls and employment increases in the short run. The spillover effect of a domestic technology shock is therefore a reduction of foreign welfare in the short run. This negative welfare spillover is soon reversed, due to the changes in the paths of foreign consumption and employment (output).

\subsection{Technology Shocks and Employment: Varying Key Pa- rameter Values}

In this section we implement a sensitivity analysis to assess how responsive the effects of technology shocks on employment are to changes in key parameter values. The above discussion suggests that the behavior of employment is dependent on the strength of the expenditure switching effect. Thus, we study how sensitive the results are to changes in the consumption elasticity of money demand, the elasticity of substitution between domestic and foreign goods and the speed of price adjustment.

Helliwell et at. (1990) estimated that the consumption elasticity of M1 is $0.85(\varepsilon=1.18)$ for the U.S. and $0.55(\varepsilon=1.8)$ for Japan (Betts and Devereux 2001, 30). Panels (a) through (c) in Figure 2 show the consequences of varying the consumption elasticity of money demand. The solid lines show the PCP baseline case which is analyzed in the previous section. The dashed lines demonstrate the LCP case where $\varepsilon=1.8$ and the solid lines with stars show the PCP case where $\varepsilon=1.8$.

In the case of PCP, a lower consumption elasticity of money demand implies that the relative demand for domestic money increases by less than in the baseline case $(\varepsilon=1.18)$. Thus, the exchange rate also depreciates less. In this case, the exchange rate movement causes a smaller change in the international price ratio. The expenditure switching effect is thus weaker and the decline in employment is smaller than in the PCP baseline case. However, a shift in world demand implies that the decline in employment is still greater and more persistent than in the LCP case.

Another important parameter is the elasticity of substitution between domestic and foreign goods for two reasons. As shown by Obstfeld and Rogoff $(1995,1996)$, it is a key variable in determining the exchange rate response and it also governs the strength of the reallocation in world demand. Panels (d) though (f) illustrate the effects of varying the elasticity of substitution between goods. Now the solid lines with stars show the PCP case where $\theta=3(\varepsilon=1.18$ as in the baseline case) and the dashed lines 
show the corresponding LCP case. Panel (d) demonstrates that the lower the elasticity of substitution between goods, the smaller the exchange rate effect of a technology shock. This and the fact that domestic and foreign goods are now poorer substitutes imply that the exchange rate change leads to a smaller shift in world demand with present prices. The expenditure switching effect anyway implies that the decline in employment is higher and more persistent than in the LCP benchmark.

Panels (g) and (h) in Figure 2 illustrate the consequences of varying the degree of price inertia. The sold line with stars indicate the PCP case where the fraction of firms setting a new price in each period is increased to 0.5 $(\theta=6, \varepsilon=1.18)$. This implies an average delay of 2 periods between price adjustments. As prices become more flexible, the expenditure switching effect becomes weaker and it dies out faster.

One general lesson from this section is that the effect of a technology shock on domestic output and employment greatly depends on the strength of the expenditure switching effect. In the case of PCP, a technology shock can has a positive or negative effect on output depending on parameter values, but the expenditure switching effect in any case induces a fall in domestic employment, when compared with the LCP benchmark. The stronger the expenditure switching effect, the higher the decline in domestic employment.

We do not show but the effect of a domestic technology shock on foreign output, in the case LCP, is sensitivity to the choice of parameter values. Hence, the result shown in Section 3.2 is not general. Depending on parameterization, a technology shock can cause a rise or fall in foreign output. The effect, with relevant parameter values, is quite small.

\subsection{Discussion: Technology Shocks and Employment}

As mentioned in the introduction, the empirical literature has shown that a technology shock causes a temporary, though persistent and significant, decline in employment. After the initial response, employment and output start to gradually increase. In the long run, employment rises close to the pre-shock level and output reaches a permanently higher level.

Gali (1999) put forward a nominal explanation to explain why the response of employment to a technology shock is negative in the short run. In his model, insufficient aggregate demand, because of present prices, accounts for the negative response of employment to a technology shock.

This paper shows that the open economy dimension can enhance the ability of sticky price models to account for the empirical evidence. The reason for this is that in open economies, there is an additional factor that causes a decline in employment and output in the short run: the expenditure switching effect. In the case of PCP, a shift in world demand causes an additional decline in domestic employment in the short run. The decline 
in employment is therefore sharper and more persistent in open economies. In addition, the model matches the empirical findings quite well. Perhaps, however, the baseline calibration with relatively sticky prices and the fact that the steady state import share is 50 percent overemphasize the role of the expenditure switching effect.

Collard and Dellas $(2004,2007)$ develop a two-country flexible-price RBC model to show that a technology shock can cause a decline in employment if the elasticity of substitution between domestic and foreign goods is very low. ${ }^{4}$ In their framework, sufficiently low substitutability implies that a technology shock induces a significant deterioration of the terms of trade. This deterioration discourages domestic output expansion and employment can decline because the level of output increases less than proportionally to the increase in productivity.

The finding of this paper is different than that of Collard and Dellas (2004, 2007) - under PCP. With present prices, a high elasticity of substitution between domestic and foreign goods implies that the expenditure switching effect is powerful. Hence, the higher the elasticity of substitution between domestic and foreign goods, the more a technology shock declines domestic employment.

Also the new open economy macroeconomics (NOEM) literature has analyzed the effects of technology shocks. A limitation of many of NOEM models (including Obstfeld and Rogoff 1996) is that technology shocks are modeled as shocks to the parameter that captures the disutility of labor. ${ }^{5}$ This is more a change in preferences (a labor supply shock) than a technology shock, as already noted by Obstfeld and Rogoff $(1996,699)$. In this type of a technology shock, households increase their labor supply immediately.

Corsetti and Pesenti (2005) develop a NOEM model, in which technology shock are modeled as a shock to the production technology, to analyze how the effects of a technology shock depend on the currency of export pricing. In their framework, the assumption of unitary elasticity of substitution between domestic and foreign goods implies that technology shocks do not have an effect on the nominal exchange rate. Hence, the international transmission of technology shocks is completely independent of the currency of export pricing. A technology shock causes a decline in domestic employment, exactly as in the closed economy case (Corsetti and Pesenti 2005, Section 6.2). In this paper, it is demonstrated that if the elasticity of substitution between domestic and foreign goods is not one, the currency of export pricing matters for the response of employment to a technology shock.

\footnotetext{
${ }^{4}$ In Collard and Dellas (2004) employment declines if the elasticity is less than one.

${ }^{5}$ NOEM models in which model technology shocks are modeled as shocks to the production technology include, but are not limited to, Benigno and Thoenissen (2003), Corsetti, Dedola and Leduc (2004), Evers (2006), Ortega and Rebei (2006), Rabanal and Tuesta (2006). These papers, however, to not address the issue of this paper.
} 


\section{Conclusions}

In recent years, the empirical literature has shown that technological improvements cause temporary, though persistent and significant, declines in employment. This paper presents a model which illustrates that the open economy dimension can enhance the ability of sticky price models to account for this empirical finding. In this paper, it is shown that the expenditure switching effect can be one reason why technology shocks have a negative effect on employment in the short run. 


\section{References}

[1] Anderson, J.E. and Van Wincoop, E. (2004). "Trade Costs," Journal of Economic Literature 42(3), pp. 691-751.

[2] Basu, S., Fernald, J. and Kimball, M. (2004). "Are Technology Improvements Contractionary?," NBER Working Paper 10592.

[3] Benigno, G. and Thoenissen C. (2003). "Equilibrium Exchange Rates and Supply-Side Performance," Economic Journal, 113(486), pp. C103C124.

[4] Betts, C. and Devereux, M. (2000). "Exchange Rate Dynamics in a Model of Pricing-to-Market," Journal of International Economics 50(1), pp. 215-244.

[5] Betts, C. and Devereux, M. (2001). "The International Effects of Monetary and Fiscal Policy in a Two-Country Model." In Calvo, G., Dornbusch, R. and Obstfeld, M. (eds.) Money, Capital Mobility and Trade: Essays in Honor of Robert Mundell, pp. 9-52, MIT Press, Cambridge.

[6] Calvo, G. (1983). "Staggered Prices in a Utility Maximizing Framework," Journal of Monetary Economics 12(3), pp. 383-398.

[7] Carlsson, M. (2003), "Measures of Technology and the Short-Run Responses to Technology Shocks," Scandinavian Journal of Economics $105(4)$, pp. 555-579.

[8] Collard, F. and Dellas, H. (2004). "Supply Shocks and Employment in an Open Economy," Economics Letters 82(2), pp. 231-237.

[9] Collard, F. and Dellas, H. (2007). "Technology Shocks and Employment," Economic Journal forthcoming.

[10] Corsetti, G., Dedola, L. and Leduc, S (2004). "International RiskSharing and the Transmission of Productivity Shocks," EBC Working Paper 308.

[11] Corsetti, G. and Pesenti, P. (2005). "The Simple Geometry of Transmission and Stabilization in Closed and Open Economy," NBER Working Paper 11341.

[12] Christiano, L., Eichenbaum, M. and Vigfusson, R. (2004). "The Response of Hours to a Technology Shock: Evidence Based on Direct Measures of Technology," Journal of the European Economic Association 2(2-3), pp. 381-395.

[13] Evers, M. (2006). "Federal Fiscal Transfers in Monetary Unions: A NOEM Approach. International Tax and Finance 13(4), pp. 463-488. 
[14] Francis, N., Owyang, N. and Theodorou, A. (2003). "The Use of LongRun Restrictions for the Identification of Technology Shocks," Federal Reserve Bank of St. Louis Review 85(6), pp. 53-66.

[15] Francis, N. and Ramey, V.A. (2004)."The Source of Historical Economic Fluctuations: An Analysis using Long-Run Restrictions," NBER Working Paper 10631.

[16] Francis, N. and Ramey, V.A. (2005). "Is the Technology-Driven Real Business Cycle Hypothesis Dead? Shocks and Aggregate Fluctuations Revisited," Journal of Monetary Economics 52(8), pp. 1379-1399.

[17] Franco, F. and Philippon, T. (2007). "Firms and Aggregate Dynamics," Review of Economic and Statistics forthcoming.

[18] Gali, J. (1999). "Technology, Employment, and the Business Cycle: Do Technology Shocks Explain Aggregate Fluctuations?," American Economic Review 89(1), pp. 249-271.

[19] Gali, J. (2003). "New Perspectives on Monetary Policy, Inflation, and the Business Cycle," in Dewatripont, M., Hansen, L. and Turnovsky, S. (eds.) Advances in Economic Theory vol. III, pp. 151-197, Cambridge University Press, Cambridge.

[20] Gali, J. (2004). "On the Role of Technology Shocks as a Source of Business Cycles: Some New Evidence," Journal of the European Economic Association 2(2-3), pp. 372-380.

[21] Gali, J. and Rabanal, P. (2004). "Technology Shocks and Aggregate Fluctuations: How Well Does the Real Business Cycle Model Fit Postwar U.S. Data?," NBER Macroeconomics Annual 19, pp. 225-228.

[22] Helliwell, J., Conderline, J. and Lafrance, R. (1990). "Multi-Country Modelling of Financial Markets," in Hooper, P., Johnson, K., Kohn, D., Lindsey, D., Porter, R. and Tryon, R. (eds.) Financial Sectors in Open Economies: Empirical Analysis and Policy Issues, pp. 305-356, Board of Governors of the Federal Reserve System, Washington.

[23] Klein, P. (2000). "Using the Generalized Schur Form to Solve a Multivariate Linear Rational Expectations Model," Journal of Economic Dynamics and Control 24(10), pp. 1405-1423.

[24] Mankiw, N. G. and Summers, L. H. (1986). "Money Demand and the Effects of Fiscal Policies," Journal of Money, Credit and Banking 18(4), pp. $415-429$.

[25] Obstfeld, M. and Rogoff, K. (1995). "Exchange Rate Dynamics Redux," Journal of Political Economy 103(3), pp. 624-660. 
[26] Obstfeld, M. and Rogoff, K. (1996). "Foundations of International Macroeconomics," MIT Press, Cambridge.

[27] Obstfeld, M. and Rogoff, K. (2000a). "Six Major Puzzles in International Macroeconomics: Is There a Common Cause?," NBER Macroeconomics Annual 15, pp. 339-390.

[28] Obstfeld, M. and Rogoff, K. (2000b). "New Directions for Stochastic Open Economy Models," Journal of International Economics 50(1), pp. $117-153$.

[29] Ortega, E. and Rebei, N. (2006). "The Welfare Implications of Inflation versus Price-Level Targeting in a Two-Sector, Small Open Economy,". Bank of Canada Working Paper 2006-12.

[30] Rabanal, P. and Tuesta V. (2006). "Euro-Dollar Real Exchange Rate Dynamics in an Estimated Two-Country Model: What Is Important and What Is Not," IMF Working Paper 06/177.

[31] Rotemberg, J. (2003). "Stochastic Technical Progress, Smooth Trends, and Nearly Distinct Business Cycles,"American Economic Review 93(5), pp. 1543-1559.

[32] Rotemberg, J. and Woodford, M. (1992). "Oligopolistic Pricing and the Effects of Aggregate Demand on Economic Activity," Journal of Political Economy 100(6), pp. 1153-1207.

[33] Sutherland, A. (1996). "Financial Market Integration and Macroeconomic Volatility," Scandinavian Journal of Economics 98(4), pp. 521539 .

[34] Uhlig, H. (2004). "Do Technology Shocks Lead to a Fall in Total Hours Worked?," Journal of the European Economic Association 2(2-3), pp. $361-371$. 
Figure 1: The macroeconomic effects of an unexpected increase in domestic productivity

(a) Domestic output

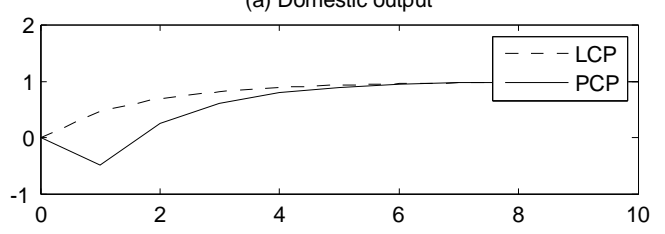

(d) Foreign output

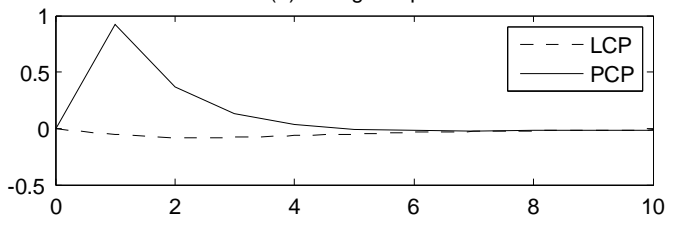

(e) Domestic employment

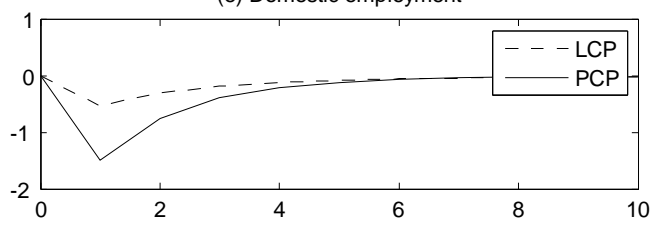

(g) Bond holdings of domestic households

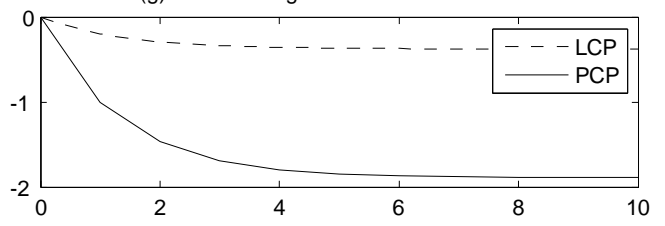

(i) Domestic welfare

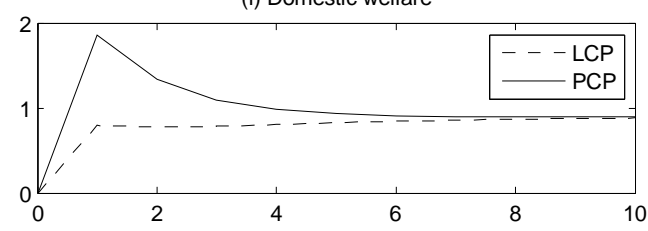

(b) Domestic consumption

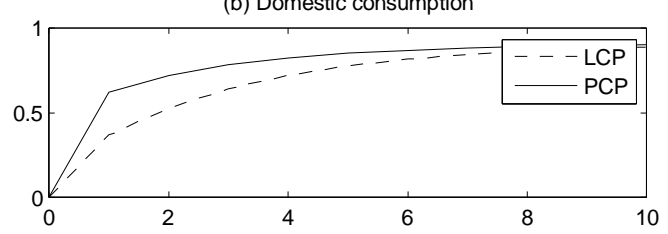

(c) Foreign consumption

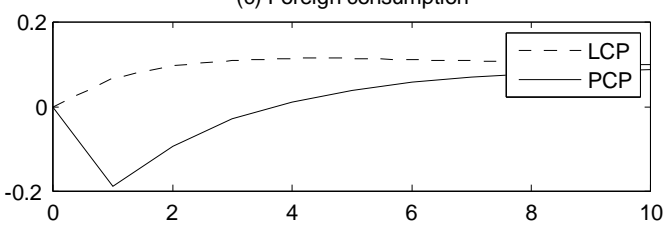

(f) Nominal exchange rate

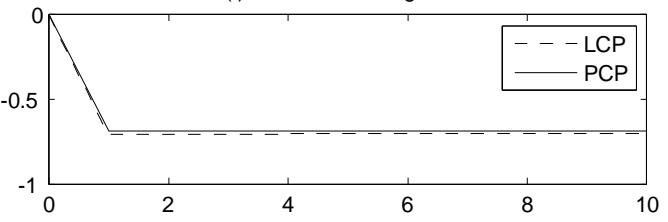

(h) Domestic terms of trade

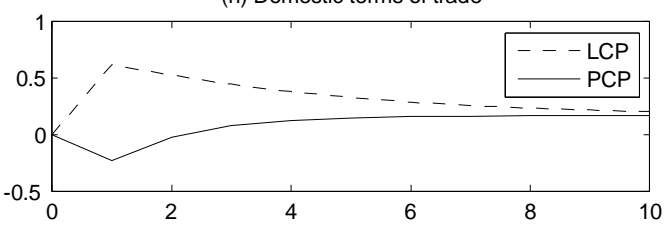

(j) Foreign welfare

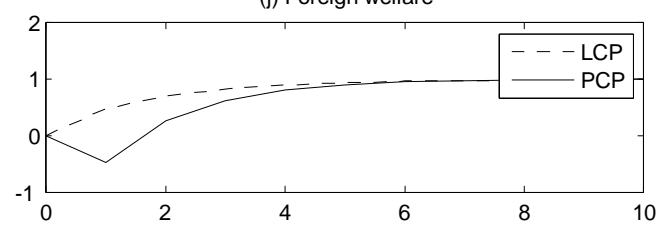


Figure 2: The effects of varying key parameter values

(a) Nominal exchange rate

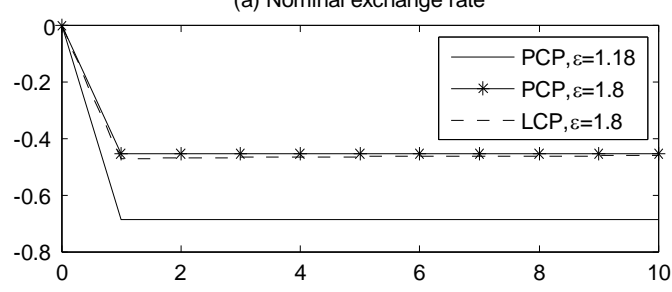

(c) Domestic employment

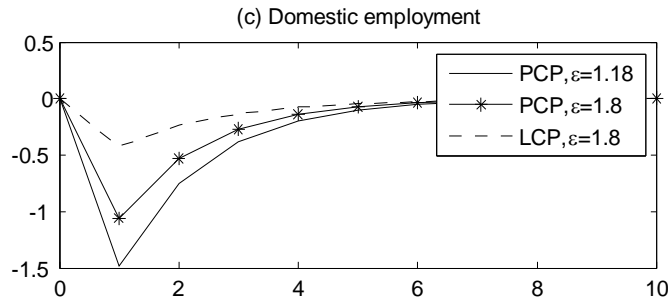

(e) Domestic output

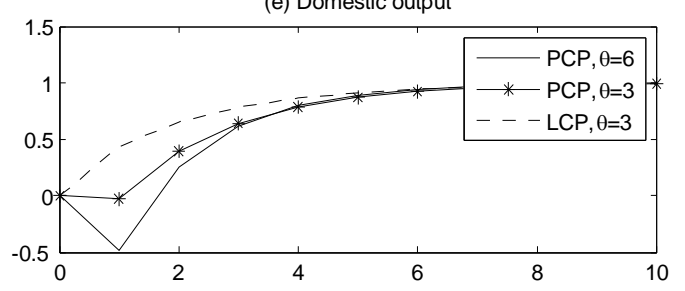

(g) Domestic output

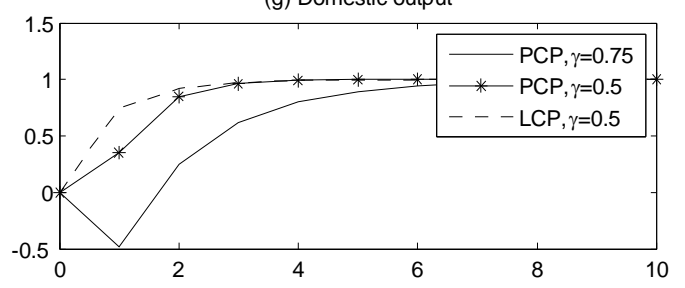

(b) Domestic output

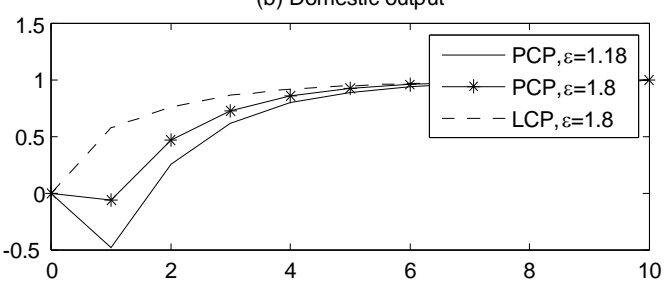

(d) Nominal exchange rate

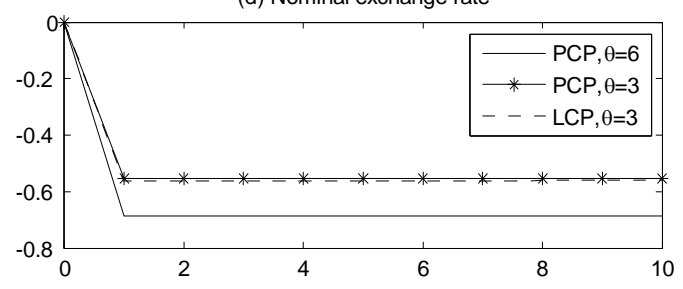

(f) Domestic employment

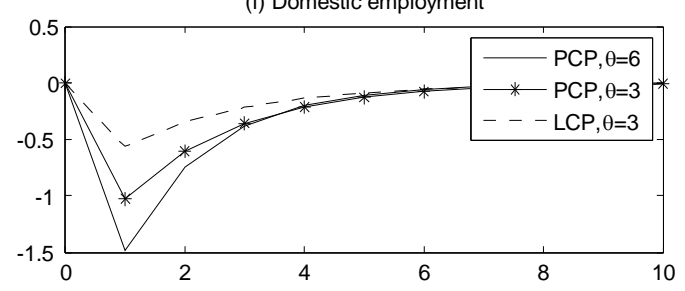

(h) Domestic employment

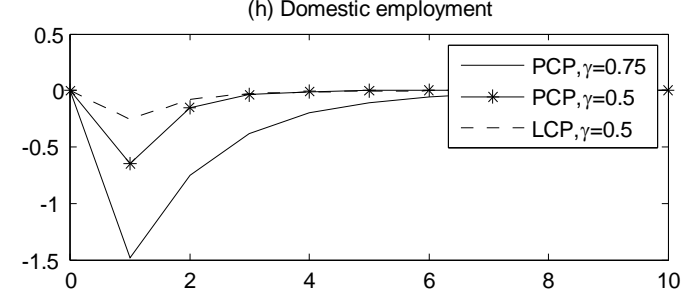

